\title{
Denying contraceptive choice to women with a previous ectopic pregnancy
}

\author{
Diana J Mansour, ${ }^{1}$ Laura Percy ${ }^{2}$
}

\begin{abstract}
${ }^{1}$ New Croft Centre, Newcastle upon Tyne, UK

${ }^{2}$ Conifer House, Hull, UK
\end{abstract}

\section{Correspondence to} Dr Diana J Mansour, Consultant in Community Gynaecology and Reproductive Healthcare, New Croft Centre, Market Street (East), Newcastle upon Tyne NE1 6ND; Diana.Mansour@nuth. nhs.uk

Received 6 December 2016 Revised 13 February 2017 Accepted 27 February 2017 Published Online First 27 March 2017
We rarely see women die in our field of medicine. However, one of the authors (DJM) vividly remembers a moribund woman being carried into an accident and emergency department by her employer, having collapsed at work due to a ruptured ectopic pregnancy. That memory was triggered by a patient seen recently in a complex contraception clinic. She was in her early twenties and had previously required admission to the local intensive care unit following a catastrophic haemorrhage due to injury to her internal iliac artery during laparoscopic surgery for an ectopic pregnancy. Her pregnancy had been unplanned and she had been anxious to avoid any further accidental pregnancies. She had spoken to the gynaecologist before discharge and had been offered a combined pill as this was "just the thing for women who had experienced an ectopic" as it suppressed ovulation.

However, just 4 months later she was pregnant again. She was sure that she had not missed any pills. She opted to have an abortion, following which she agreed to have an implant fitted as she was told that "this was the only other option". She was seen 18 months later complaining of prolonged, erratic bleeding. She requested implant removal but was not ready to have children - or to risk another ectopic pregnancy. She was uncertain about what contraception to choose as she had been told that intrauterine contraceptives "increased the risk of ectopics" and that injectables caused bleeding problems like the implant.

So what are the facts (see Table 1)? All effective contraceptive methods reduce the risk of ectopic pregnancy when compared with no contraception. There are few published studies about the risk of ectopic pregnancy with combined oral contraception (COC) and none for the patch or vaginal ring. The Contraceptive CHOICE project in St Louis, MI, USA suggested that when COCs fail the risk of ectopic pregnancy is very low. ${ }^{1}$ There is very little information about the incidence of ectopic pregnancies in women taking progestogen-only pills (POPs) or using injectables, but pragmatically a desogestrel POP or depot medroxyprogesterone acetate (DMPA) suppress ovulation with low failure rates, so should also be suitable contraceptive choices. The authors of a Cochrane Review investigating the efficacy of Implanon ${ }^{\circledR}$, the predecessor of Nexplanon ${ }^{\circledR}$, stated that pregnancies, including ectopics, rarely occur in etonogestrel implant users. ${ }^{2}$

However, things become more complex when interrogating the literature relating to intrauterine contraception. Copper intrauterine devices (IUDs), particularly those bearing $300 \mathrm{~mm}^{2}$ or more of copper, are highly effective, with the ectopic pregnancy rate being very low. Hormonal intrauterine systems may be different. Progestasert ${ }^{\circledR}$, the first hormone-releasing IUD, containing $38 \mathrm{mg}$ micro-crystallised progesterone, was withdrawn from sale some 30 years ago following a number of concerns including the risk of ectopic pregnancy. Levonorgestrel-releasing intrauterine systems (LNG-IUS) containing $52 \mathrm{mg}$ levonorgestrel (IUS-52) may be more effective than the newer lower dosage IUS-13.5 and IUS-19.5, although there are no comparative data available and limited numbers of women were recruited to the studies of the lower-dosage devices. The UK Medical Eligibility Criteria for Contraceptive Use (UKMEC) $^{3}$ classify past ectopic pregnancy as UKMEC Category 1 (a condition for which there is no restriction for the use of the method) for both copperbearing IUDs and the LNG-IUS and we would therefore suggest that an IUS-52 or an IUD with $380 \mathrm{~mm}^{2}$ of copper would be appropriate for women with a past history of an extra-uterine pregnancy. 
Table 1 Pregnancy rates in studies of prescribed methods of contraception

\begin{tabular}{|c|c|c|c|}
\hline Method & Pregnancy rate & Ectopic pregnancy rate & References \\
\hline $\begin{array}{l}\text { Ectopic pregnancy rate in a population of women aged } \\
15-44 \text { years }\end{array}$ & Not available & 0.211 per 100 woman-years & 6 \\
\hline $\mathrm{COC}$ & 4.55 per 100 woman-years & 0.039 per 100 woman-years & 17 \\
\hline $\begin{array}{l}\text { POP - Levonorgestrel/norethisterone/ethynodiol } \\
\text { diacetate }\end{array}$ & 0.2 per 100 woman-years & Zero & 8 \\
\hline Desogestrel & 1 in 727 woman-years & Not available & 9 \\
\hline DMPA & 0.22 per 100 woman-years & Not available & 7 \\
\hline $\begin{array}{l}\text { Implants - Etonogestrel } \\
\text { Implanon®/Nexplanon } ®\end{array}$ & 0 per 100 woman-years & Zero & 2 \\
\hline IUS-52 - Mirena®/Levosert@ & 0.06 per 100 woman-years & $\begin{array}{l}0.02 \text { per } 100 \text { woman-years ( } 27 \% \text { of all } \\
\text { pregnancies were ectopic) }\end{array}$ & 10 \\
\hline IUS-19.5 - Phase III studies & 0.31 per 100 woman-years & $\begin{array}{l}0.22 \text { per } 100 \text { woman-years ( } 70 \% \text { of all } \\
\text { pregnancies were ectopic) }\end{array}$ & 11 \\
\hline IUS-13.5 - Jaydess $®$ & 0.33 per 100 woman-years & $\begin{array}{l}0.1 \text { per } 100 \text { woman-years ( } 30 \% \text { of all } \\
\text { pregnancies were ectopic) }\end{array}$ & 11 \\
\hline Copper IUD (200-380 mm² copper) & 0.52 per 100 woman-years & $\begin{array}{l}0.08 \text { per } 100 \text { woman-years ( } 15 \% \text { of all } \\
\text { pregnancies were ectopic) }\end{array}$ & 10 \\
\hline
\end{tabular}

COC, combined oral contraception; DMPA, depot medroxyprogesterone acetate; IUD, intrauterine device; IUS, intrauterine system; POP, progestogen-only pill.

Lastly, what if our patient had requested emergency contraception (EC)? An IUD with $380 \mathrm{~mm}^{2}$ would be our first choice but may not be hers. Cleland et $a l .{ }^{4}$ undertook a comprehensive review of the literature and found that there was no cause for concern. Ectopic pregnancy rates with hormonal EC do not exceed the background rate for ectopic pregnancy in the general population. ${ }^{4}$ This finding is also supported by a prospective cohort study in women taking ulipristal acetate or levonorgestrel EC. ${ }^{5}$

So what contraceptive method did our patient choose? After discussing the options she initially thought about trying the IUS-52 but then preferred the idea of self-administering DMPA, which she had used in the past with very little bleeding.

And what did we learn from this case? Don't deny a patient contraceptive choice through ignorance. When in doubt, ask a local sexual and reproductive health specialist or consult the UK Medical Eligibility Criteria, ${ }^{3}$ published online by the Faculty of Sexual \& Reproductive Healthcare.

Contributors DM wrote the article with LP constructing the table and performing the literature search.

Competing interests None declared.

Provenance and peer review Not commissioned; externally peer reviewed.

(C) Faculty of Sexual and Reproductive Healthcare of the Royal College of Obstetricians and Gynaecologists (unless otherwise stated in the text of the article) 2017. All rights reserved. No commercial use is permitted unless otherwise expressly granted.

\section{REFERENCES}

1 Williams S, Peipert J, Buckel C, et al. Contraception and the risk of ectopic pregnancy. Contraception 2014;90:326.
2 Power J, French R, Cowan F. Subdermal implantable contraceptives versus other forms of reversible contraceptives or other implants as effective methods for preventing pregnancy. Cochrane Database Syst Rev 2007;3:CD001326.

3 Faculty of Sexual \& Reproductive Healthcare. UK Medical Eligibility Criteria for Contraceptive Use. UKMCE. 2016. https://www.fsrh.org/standards-and-guidance/documents/ ukmec-2016/016 (accessed on 11 Feb 2017).

4 Cleland K, Raymond E, Trussell J, et al. Ectopic pregnancy and emergency contraceptive pills: a systematic review. Obstet Gynecol 2010;115:1263-6.

5 Glasier AF, Cameron ST, Fine PM, et al. Ulipristal acetate versus levonorgestrel for emergency contraception: a randomised non-inferiority trial and meta-analysis. Lancet 2010;375:555-62.

6 Trabert B, Holt VL, Yu O, et al. Population-based ectopic pregnancy trends, 1993-2007. Am J Prev Med 2011;40:556-60.

7 Winner B, Peipert JF, Zhao Q, et al. Effectiveness of long-acting reversible contraception. N Engl J Med 2012;366:1998-2007.

8 Broome M, Fotherby K. Clinical experience with the progestogen-only pill. Contraception 1990;42:489-95.

9 Collaborative Study Group on the Desogestrel-containing Progestogen-only Pill. A double-blind study comparing the contraceptive efficacy, acceptability and safety of two progestogen-only pills containing desogestrel 75 micrograms/ day or levonorgestrel 30 micrograms/day. Eur J Contracept Reprod Health Care 1998;3:169-78.

10 Heinemann K, Reed S, Moehner S, et al. Comparative contraceptive effectiveness of levonorgestrel-releasing and copper intrauterine devices: the European Active Surveillance Study for Intrauterine Devices. Contraception 2015;91:280-3.

11 Nelson A, Apter D, Hauck B, et al. Two low-dose levonorgestrel intrauterine contraceptive systems: a randomized controlled trial. Obstet Gynecol 2013;122:1205-13. 